\title{
Development of A Web-Based Recitation Program with Multiple Representations on Kinematics Material
}

\author{
Alfiana Dewi Febryanti ${ }^{1)}$, Muhammad Reyza Arief Taqwa ${ }^{2)}$ \\ ${ }^{1,2)}$ State University of Malang \\ e-mail: alfianadewif.1703216@students.um.ac.id \\ reyza.arief.fmipa@um.ac.id
}

\begin{abstract}
This research aims to develop a web-based recitation program with multiple representations of kinematics material and to determine the feasibility of the product being developed. The recitation program aims to make it easier for students to deepen kinematics material outside lecture hours. This study uses the Research and Development $(R \& D)$ method with a $4 D$ model development design consisting of 4 stages, namely defining, designing, developing, and disseminating. The data obtained from this research are quantitative data obtained from questionnaire assessment scores on the validation sheet and practicality test sheets based on the Likert scale, as well as qualitative data obtained from suggestions/comments from validators and students. The validity test was carried out by 1 physics lecturer at the State University of Malang and 2 physics lecturers outside UM, while the practicality test was carried out on 60 UM physics students who had obtained kinematics material. The data analysis technique used is the descriptive qualitative analysis and descriptive statistical analysis. In this research, the results of the data analysis of the program display validation were $87.67 \%$ and the results of the content validation data analysis were $93.31 \%$ with the valid category. While the practicality test obtained a percentage of $84.33 \%$ with practical criteria. The validation results and practicality test results show that the products developed are valid and suitable for use by students as independent teaching materials.
\end{abstract}

Keywords: multiple representation recitation program, web. 


\title{
Pengembangan Program Resitasi Berbasis Web dengan Multirepresentasi pada Materi Kinematika
}

\author{
Alfiana Dewi Febryanti11), Muhammad Reyza Arief Taqwa ${ }^{2)}$ \\ ${ }^{1,2)}$ Universitas Negeri Malang
}

\begin{abstract}
Abstrak
Penelitian ini bertujuan untuk mengembangkan program resitasi berbasis web dengan multirepresentasi pada materi kinematika, serta mengetahui kelayakan dari poduk yang dikembangkan. Program resitasi bertujuan untuk mempermudah mahasiswa dalam memperdalam materi kinematika di luar jam perkuliahan. Penelitian ini menggunakan metode Research and Development (R\&D) dengan desain pengembangan model 4D yang terdiri dari 4 tahap, yaitu pendefinisian (define), perancangan (design), pengembangan (develop), dan penyebaran (disseminate). Data yang diperoleh dari penelitian ini berupa data kuantitatif yang diperoleh dari skor penilaian angket pada lembar validasi dan lembar uji kepraktisan yang beracuan pada skala likert, serta data kualitatif yang diperoleh dari saran/komentar validator dan mahasiswa. Uji kevalidan dilakukan oleh 1 dosen fisika Universitas Negeri Malang dan 2 dosen fisika luar UM, sedangkan uji kepraktisan dilakukan pada 60 mahasiswa fisika UM yang telah memperoleh materi kinematika. Teknik analisis data yang digunakan yaitu analisis deskriptif kualitatif dan analisis statistik deskriptif. Dalam penelitian ini diperoleh hasil analisis data validasi tampilan program sebesar $87,67 \%$ dan hasil analisis data validasi isi sebesar 93,31\% dengan kategori valid. Sedangkan uji kepraktisan diperoleh persentasi $84,33 \%$ dengan kriteria praktis. Hasil validasi dan hasil uji kepraktisan menunjukkan bahwa produk yang dikembangkan valid dan layak untuk digunakan mahasiswa sebagai bahan ajar mandiri.
\end{abstract}

Kata kunci: multirepresentasi, program resitasi, web.

\section{Pendahuluan}

Tujuan penting dari pembelajaran fisika yaitu untuk memfasilitasi peserta didik dalam memahami konsep-konsep fundamental dan menerapkannya dalam masalah fisika yang berkaitan. Konsep yang benar secara ilmiah berguna dalam membantu siswa menyelesaikan masalah berdasarkan konsep yang tepat. Pemahaman konsep dasar peserta didik dapat digunakan dalam mempelajari konsep fisika berikutnya yang lebih kompleks. Oleh karena itu, setelah pembelajaran fisika seharusnya peserta didik dapat memecahkan konsep secara baik (Docktor \& Mestre, 2014). Namun kenyataannya masih banyak peserta didik yang kesulitan menyelesaikan permasalahan yang mengenai konsep fisika (Pratiwi et al., 2018).

Kinematika merupakan salah satu cabang ilmu fisika yang mempelajari konsep dasar mekanika dan termasuk dalam salah satu kajian fundamental pada program studi pendidikan fisika (Handhika et al., 2015). Selain itu, konsep kinematika berhubungan langsung dengan fenomena alam dalam kehidupan sehari-hari (Firdaus \& Sinensis, 2017) dan digunakan sebagai dasar untuk mempelajari materi selanjutnya, seperti usaha dan energi (Yusro \& Sasono, 2016). Oleh karena itu, konsep kinematika termasuk dalam salah satu konsep penting yang perlu dikuasai oleh peserta didik (Purwanti et al., 2017). Peserta didik perlu memahami konsep-konsep yang kokoh tentang konsep-konsep posisi, kecepatan dan percepatan secara konseptual maupun secara perhitungan untuk memahami konsep kinematika dengan baik (Pratiwi et al., 2018). Namun, hasil penelitian terdahulu menunjukkan bahwa mahasiswa masih kesulitan dalam memahami konsep kinematika.

Mahasiswa mengungkapkan bahwa topik kinematika cukup sulit untuk dipelajari, sehingga mahasiswa kesulitan dalam memecahkan masalah yang diberikan. Hal tersebut ditunjukkan dengan hasil tes kinematika mahasiswa yang tergolong rendah, dimana hanya $28 \%$ mahasiswa yang memperoleh nilai di atas rata-rata (Sukadi \& Angraeni, 2019). Salah satu kesulitan yang sering dialami mahasiswa dalam memahami konsep 
kinematika yaitu dalam menginterprestasikan grafik. Subali et al., (2015) mengungkapkan bahwa mahasiswa kesulitan dalam merumuskan persamaan matematik dari grafik kinematika. Selain itu, hasil penelitian Kirana \& Kusairi (2019) juga menyimpulkan bahwa mahasiswa masih kesulitan dalam menentukan kecepatan sesaat dari grafik posisi terhadap waktu dan menentukan perpindahan dari grafik kecepatan terhadap waktu.

Mahasiswa dalam proses pembelajaran tidak hanya dituntut memahami konsep secara utuh, melainkan juga dapat menerapkannya dalam permasalahan fisika. Dalam membangun pemahaman peserta didik dengan memberikan informasi yang lengkap dari berbagai bentuk yang disajikan diperlukan multirepresentasi (Widianingtiyas et al., 2015). Penggunaan multirepresentasi sebagai solusi untuk memperluas dan memperdalam wawasan mahasiswa pada suatu konsep.

Multirepresentasi merupakan penyampaian suatu konsep melalui berbagai cara dan bentuk (Ningrum et al., 2015). Menurut Waldrip et al. (2006) multirepresentasi berarti merepresentasikan ulang konsep yang sama dengan bentuk yang berbeda-beda, meliputi verbal, grafik, gambar, dan matematik. Penggunaan multirepresentasi berpengaruh positif terhadap pemahaman konsep peserta didik dan hasil belajar fisika (Pahini et al., 2014). Multirepresentasi membantu peserta didik dalam memahami materi (Permadi et al., 2013). Multirepresentasi juga dapat digunakan pengajar untuk menjelaskan konsep abstrak, sehingga peserta didik dapat memahami makna dari suatu konsep (Widianingtiyas et al., 2015).

Kinematika termasuk dalam konsep fisika yang kompleks baik abstrak maupun real yang memerlukan penguasaan konsep dan matematis (Prastowo et al., 2019). Cakupan materi kinematika yang cukup luas memiliki tingkat kesulitan yang tinggi. Hasil penelitian mengungkapkan bahwa mahasiswa merasa cukup sulit dalam mempelajari kinematika dan tidak tertarik dengan materi kinematika (Maharani \& Kartini, 2019). Oleh karena itu, dibutuhkan cukup banyak waktu untuk siswa menyimpan secara kuat pengetahuan baru dan mengaktivasinya secara cepat ketika diperlukan (Docktor \& Mestre, 2014). Namun, alokasi waktu pembelajaran diperkuliahan yang terbatas, menjadi kendala tersendiri dalam menyampaikan materi kinematika. Dalam mengatasi keterbatasan waktu penyampaian materi pembelajaran, program resitasi sebagai solusi pendalaman konsep di luar jam pembelajaran (Taqwa, 2017).

Program resitasi merupakan suatu program pembelajaran yang menggunakan metode resitasi yaitu dilakukan dengan memberikan tugas khusus kepada peserta didik untuk mengerjakan sesuatu di luar jam pelajaran (Aditya, 2016). Penggunaan metode resitasi dapat meningkatkan pemahaman (Pebriana et al., 2018) dan penguasaan konsep mahasiswa (Sutopo et al., 2017). Program resitasi dapat berupa soalsoal konseptual disertai balikan atau feedback (Pebriana et al., 2018).

Pemberian umpan balik pada setiap opsi jawaban sangat penting untuk meningkatkan penguasaan konsep peserta didik (Abi Hamid et al. 2013). Sejalan dengan Novitasari et al. (2013) yang menyatakan bahwa pemberian umpan balik memberikan dampak positif terhadap pemahaman peserta didik dengan merespons kesulitan peserta didik dalam waktu singkat. Pemberian soal dengan jumlah yang banyak pada program resitasi tidak akan berpengaruh baik pada penguasaan konsep jika tidak disertai feedback dengan segera (Taqwa, 2017). Seiring sengan perkembangan teknologi, pemberian feedback pada program resitasi dapat diwujudkan dengan bantuan komputer maupun smartphone.

Penggunaan program dalam bentuk web mempermudah mahasiswa untuk mengakses program tersebut kapan dan dimana saja selama perangkat yang digunakan seperti smarphone atau komputer terhubung dengan jaringan internet. Sejalan dengan Dewi, (2013) yang menyatakan bahwa penggunaan website mempermudah mahasiswa untuk mengulang materi yang belum dipahami dengan mengakses program tersebut kapan saja. Oleh karena itu, dikembangkannya program resitasi berbasis web dengan multirepresentasi pada materi kinematika dengan tujuan: (1) menghasilkan produk program resitasi berbasis web dengan multirepresentasi pada materi kinematika; dan (2) mengetahui tingkat kelayakan produk program resitasi berbasis web dengan multirepresentasi pada materi kinematika. 


\section{Metode Penelitian}

Penelitian ini menggunakan metode Research and Development (R\&D) dengan model pengembangan yang digunakan dalam penelitian ini yaitu pengembangan four-D (4D) yang dikembangkan oleh Thiagarajan, et al. (1974). Model pengembangan 4D terdiri dari 4 tahap, yaitu: (1) define (pendefinisian); (2) design (perancangan); (3) develop (pengembangan); dan (4) disseminate (penyebaran). Namun dalam penelitian dan pengembangan ini hanya dilakukan tiga tahap dari empat tahap yang ditunjukkan, yaitu sampai pada tahap develop. Hal tersebut dikarenakan penelitian ini hanya bertujuan untuk menghasilkan produk dan mendeskripsikan kelayakan dari program resitasi yang dikembangkan.

Penelitian ini menggunakan uji validasi untuk mengetahui kevalidan isi dan tampilan dari program resitasi, serta uji kepraktisan untuk mengetahui tingkat kepraktisan dari program resitasi. Instrumen yang digunakan untuk pengambilan data dalam penelitian ini berupa angket validasi dan angket kepraktisan. Angket uji kepraktian teridiri dari beberapa aspek yang digunakan untuk mengetahui tingkat kelayakan produk. Pengukuran jawaban dalam angket uji validasi dan uji kepraktisan beracuan pada skala likert 1-4, seperti yang ditunjukkan pada Tabel 1 .

Tabel 1. Kategori nilai skala likert

\begin{tabular}{clc}
\hline No & \multicolumn{1}{c}{ Kategori } & Skor \\
\hline 1 & Sangat setuju & 4 \\
2 & Setuju & 3 \\
3 & Tidak setuju & 2 \\
4 & Sangat tidak setuju & 1 \\
\hline
\end{tabular}

Sumber: (Sugiyono, 2015).

Data hasil uji validasi dan uji kepraktisan berupa data kuantitatif dan data kualitatif. Data kuantitatif merupakan skor hasil pengisian angket yang dilakukan oleh 3 validator pada uji validasi dan skor hasil pengisian angket oleh 60 mahasiswa fisika UM yang telah memperoleh materi kinematika pada uji kepraktisan. Sedangkan data kualitatif diperoleh dari hasil saran/komentar yang diberikan validator pada lembar validasi dan saran/komentar yang diberikan oleh mahasiswa pada lembar uji kepraktisan.

Teknik analisis data yang digunakan untuk mengolah data hasil penelitian, yaitu dengan analisis statistik deskriptif dan analisis deskriptif kualitatif. Teknik analisis statistik deskriptif digunakan untuk menganalisis skor hasil uji validasi dan uji kepraktisan. Dalam menganalisis data hasil uji validasi dapat menggunakan teknik analisis dengan perhitungan skor rata-rata menurut persamaan (1). Adapun kriteria analisis data hasil uji validasi dapat dilihat pada Tabel 2.

$$
\bar{x}=\frac{\sum x}{n}
$$

Keterangan,

$\bar{x}=$ nilai rata-rata

$\sum x=$ jumlah skor tiap responden

$n \quad=$ banyak responden

Tabel 2. Kategori kevalidan produk

\begin{tabular}{cl}
\hline Rata-rata & \multicolumn{1}{c}{ Kategori } \\
\hline $3,26-4,00$ & Valid/ Tanpa Revisi \\
$2,51-3,25$ & Cukup Valid/ Perlu Revisi \\
$1,76-2,50$ & Kurang Valid/ Revisi \\
$1,00-1,75$ & Tidak Valid/ Revisi Total
\end{tabular}

Sumber: (Arikunto, 2013).

Sedangkan teknik yang digunakan dalam analisis data hasil uji kepraktisan adalah Teknik persentase. Adapun kriteria tingkat kepraktisan produk dapat dilihat pada Tabel 3.

Tabel 3. Kriteria kepraktisan produk

\begin{tabular}{cl}
\hline Skor & \multicolumn{1}{c}{ Kategori } \\
\hline $76 \%-100 \%$ & Praktis/ Tanpa Revisi \\
$51 \%-75 \%$ & Cukup Praktis/ Perlu Revisi \\
$26 \%-50 \%$ & Kurang Praktis/ Revisi \\
$0-25 \%$ & Tidak Praktis/ Revisi Total
\end{tabular}

Sumber: (Arikunto, 2013).

\section{Hasil dan Pembahasan}

\section{A. Hasil Pengembangan}

Produk yang dihasilkan dari penelitian dan pengembangan ini adalah program resitasi berbasis web dengan multirepresentasi pada materi kinematika. Produk yang dihasilkan memiliki format HTML (Hyper Text Markup 
Language) yang dapat diakses melalui perangkat elektronik yang terhubung dengan internet. Program resitasi pada penelitian ini dirancang dengan tujuan untuk mempermudah mahasiswa memperdalam pemahaman konsep kinematika diluar jam perkuliahan. Konsep kinematika pada program resitasi disajikan dalam bentuk soal-soal matematis maupun konseptual. Sedangkan penggunaan multirepresentasi pada program ini diaplikasikan dalam soal yang direpresentasikan dalam berbagai bentuk, yaitu tabel, video, gambar, grafik, matematis, dan verbal. Adapun rincian bagian dari program resitasi yang telah dikembangkan adalah sebagai berikut.

\section{a. Tampilan Awal}

Tampilan awal merupakan halaman awal yang akan ditampilkan ketika membuka link dari program resitasi. Tampilan awal dari program resitasi ditunjukkan oleh Gambar 1.

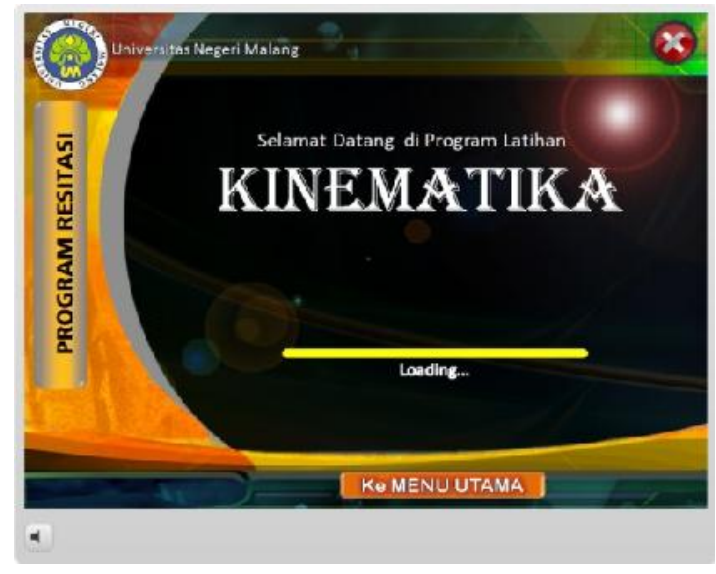

Gambar 1. Tampilan awal program.

\section{b. Menu Utama}

Menu utama (home) merupakan halaman yang menampilkan tombol-tombol untuk menuju ke halaman berikutnya. Tombol pada menu utama terdiri dari tombol untuk menuju ke halaman petunjuk navigasi, tombol untuk menuju ke halaman petunjuk penggunaan, dan tombol untuk menuju ke halaman latihan soal. Tampilah dari halaman menu utama ditunjukkan pada Gambar 2.

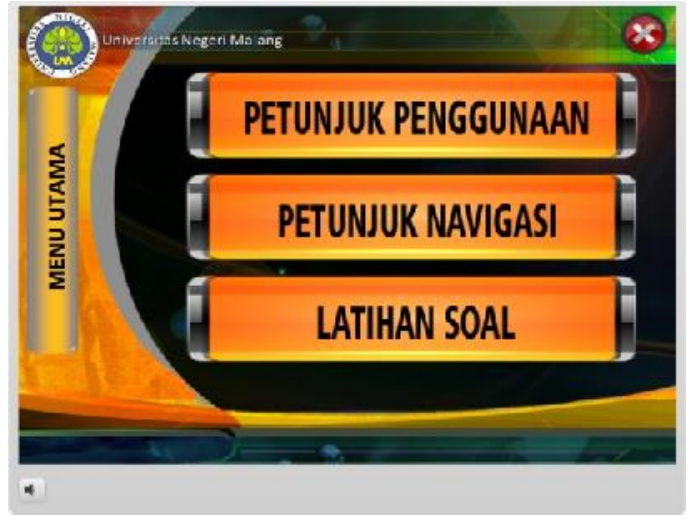

Gambar 2. Tampilan halaman menu utama.

c. Petunjuk Penggunaan

Petunjuk penggunaan berisi penjelasan tentang cara menggunakan program resitasi. Pada halaman petunjuk penggunaan terdapat tombol untuk menuju halaman menu utama. Tampilan dari halaman petunjuk penggunaan ditunjukkan pada Gambar 3.

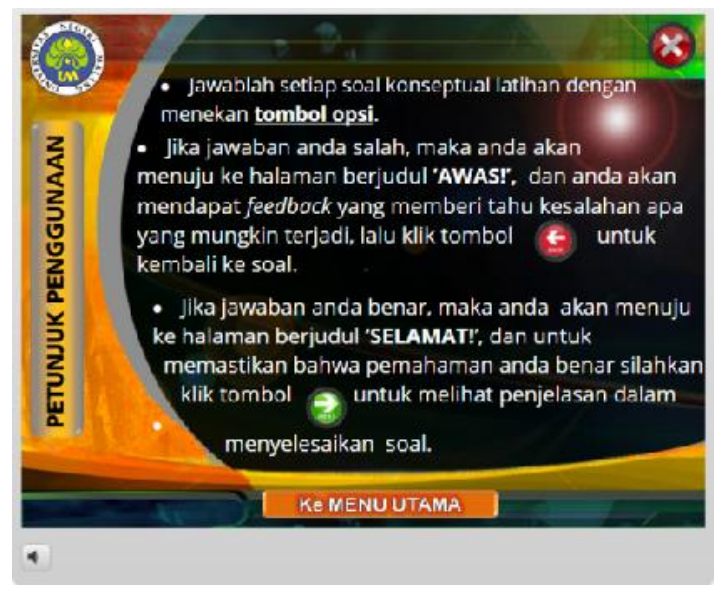

Gambar 3. Tampilan halaman petunjuk penggunaan.

d. Petunjuk Navigasi

Petunjuk navigasi berisi penjelasan kegunaan dari setiap tombol navigasi yang digunakan pada program resitasi. Pada halaman petunjuk navigasi terdapat tombol untuk menuju ke menu utama. Tampilan dari halaman petunjuk navigasi ditunjukkan pada Gambar 4. 


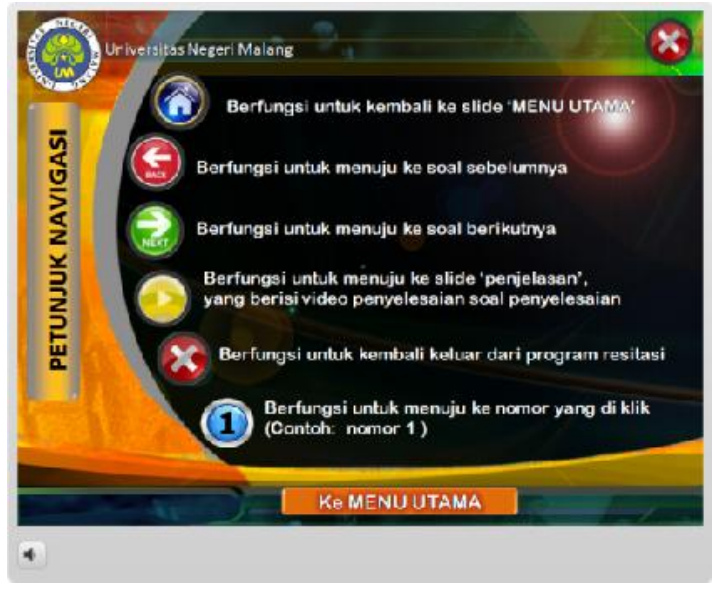

Gambar 4. Tampilan halaman petunjuk navigasi.

\section{e. Latihan Soal}

Halaman latihan soal menampilkan soal konseptual dalam berbagai representasi serta pilihan jawaban dalam beberapa opsi. Pada halaman ini terdapat tombol untuk menuju nomor soal yang diinginkan sesuai dengan nomor soal yang dipilih. Selain itu, pada halaman ini juga terdapat opsi jawaban dalam bentuk tombol, dan jika dipilih akan menuju ke halaman umpan balik. Tampilan dari halaman latihan soal ditunjukkan pada Gambar 5.

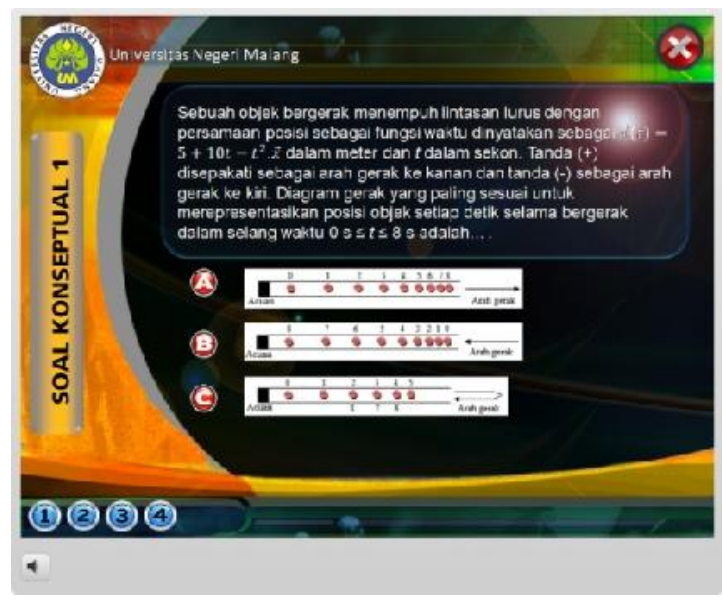

Gambar 5. Tampilan halaman latihan soal.

\section{f. Umpan Balik}

Pada halaman umpan balik untuk jawaban yang benar berisi tulisan "SELAMAT" dan terdapat tombol next untuk menuju halaman pembahasan. Sedangkan pada halaman umpan balik untuk jawaban yang salah berisi tulisan
"AWAS" dan terdapat tombol back untuk kembali ke halaman sebelumnya (halaman yang berisi soal konseptual). Tampilan dari halaman umpan balik untuk jawaban yang benar ditunjukkan pada Gambar 6, dan tampilan dari halaman umpan balik untuk jawaban yang salah ditunjukkan pada Gambar 7.

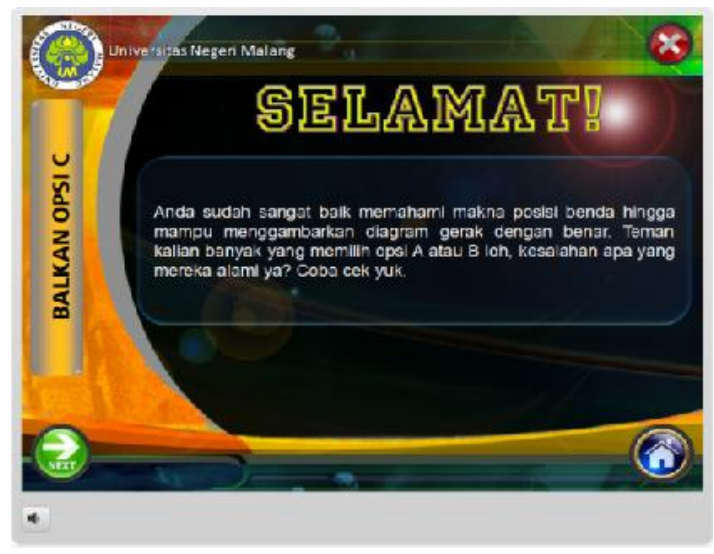

Gambar 6. Tampilan halaman petunjuk navigasi.

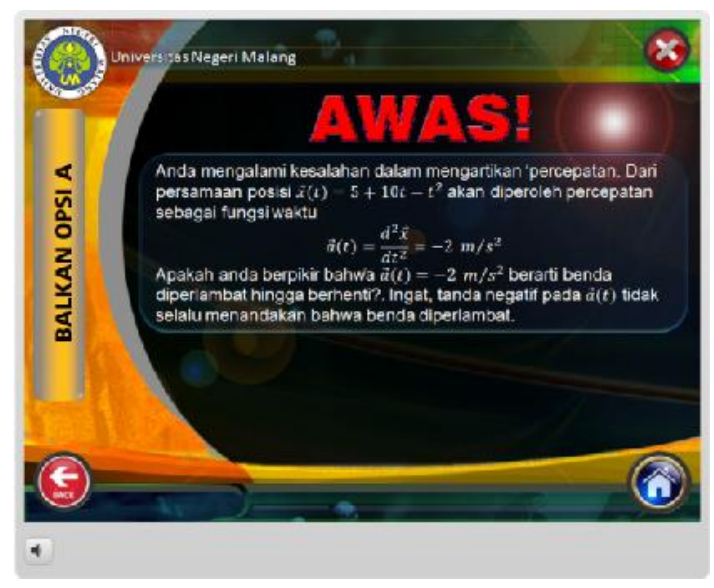

Gambar 7. Tampilan halaman umpan balik untuk jawaban salah.

\section{g. Pembahasan}

Halaman pembahasan berisi pembahasan dari soal konseptual yang telah dipilih. Penjelasan yang ditampilkan dalam halaman pembahasan berbentuk audio visual. Tampilan dari halaman pembahasan ditunjukkan pada Gambar 8. 


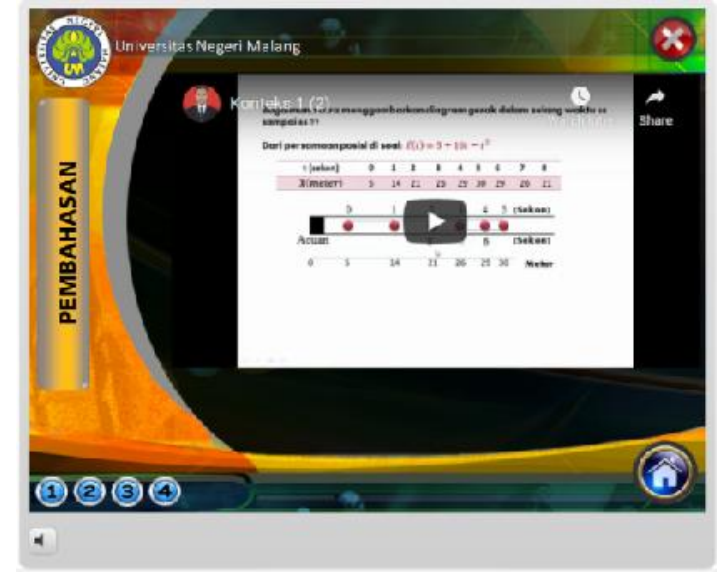

Gambar 8. Tampilan halaman pembahasan.

\section{B. Pembahasan}

Kelayakan program resitasi berbasis web dengan multirepresentasi pada materi kinematika adalah kriteria kualitas dari program resitasi yang dikembangkan.
Kelayakan program resitasi dapat dilihat dari uji validitas dan uji kepraktisan produk.

1. Hasil validasi media

Data hasil validasi produk terdiri dari data kuantitatif dan data kualitatif. Data kuantitatif diperoleh dari hasil pengisian angket validasi. Sedangkan data kualitatif diperoleh dari saran dan komentar validator. Melalui data kuantitatif dapat diketahui kevalidan dari produk yang dikembangkan. Soal-soal konseptual dalam berbagai representasi yang disajikan pada program resitasi merupakan soal yang sudah dikembangkan oleh (Taqwa, 2017). Sehingga hasil validasi isi yang digunakan disesuaikan dengan peneliti sebelumnya. Adapun hasil analisis data validasi isi program resitasi oleh validator ditunjukkan pada Tabel 4. Sedangkan hasil analisis data validasi tampilan program resitasi oleh validator ditunjukkan pada Tabel 5 .

Tabel 4. Hasil validasi isi program resitasi oleh validator

\begin{tabular}{lccc}
\multicolumn{1}{c}{ Aspek } & Rata-rata & P(\%) & Keterangan \\
\hline $\begin{array}{l}\text { Kesesuaian butir soal dengan tujuan } \\
\begin{array}{l}\text { Ketepatan balikan (Kesesuaian tujuan dan } \\
\text { kebenaran konsep) }\end{array}\end{array}$ & 3,92 & 98,11 & Valid \\
$\begin{array}{l}\text { Kejelasan soal beserta balikannya yang mudah } \\
\text { dipahami }\end{array}$ & 3,73 & 93,19 & Valid \\
\hline \multicolumn{1}{c}{ Rata-rata } & 3,54 & 88,64 & Valid \\
\hline
\end{tabular}

Tabel 5. Hasil validasi tampilan program resitasi oleh validator

\begin{tabular}{|c|c|c|c|c|c|c|}
\hline \multirow{2}{*}{ Aspek yang dinilai } & \multicolumn{3}{|c|}{ Validator } & \multirow{2}{*}{$\begin{array}{l}\text { Rata- } \\
\text { rata }\end{array}$} & \multirow{2}{*}{$\mathbf{P}(\%)$} & \multirow{2}{*}{ Keterangan } \\
\hline & VI & V2 & V3 & & & \\
\hline Gambar, Video, dan Audio & 3,25 & 3,25 & 3,25 & 3,25 & 81,25 & Valid \\
\hline Tata Letak & 3,00 & 3,67 & 3,333 & 3,33 & 83,33 & Valid \\
\hline Kelayakan bahasa & 4,00 & 4,00 & 4,00 & 4,00 & 100,00 & Valid \\
\hline $\begin{array}{l}\text { Kemudahan penggunaan } \\
\text { program resitasi }\end{array}$ & 3,33 & 3,33 & 3,667 & 3,44 & 86,11 & Valid \\
\hline \multicolumn{4}{|c|}{ Rata-rata } & 3,51 & 87,67 & Valid \\
\hline
\end{tabular}

Keterangan:

V1: Dosen Fisika Univeritas Negeri Malang

V2: Dosen Fisika Universitas Negeri Yogyakarta

V3: Dosen Fisika UIN Antasari Banjarmasin 
Berdasarkan data hasil validasi isi oleh validator pada Tabel 4 diperoleh nilai rata-rata 3,73 dengan persentase $93,31 \%$ dengan kategori valid. Hal tersebut menunjukkan bahwa pada aspek kesesuaian butir soal dengan tujuan, ketepatan balikan (kesesuaian tujuan dan kebenaran konsep), serta kejelasan soal beserta balikannya yang mudah dipahami, tergolong dalam kateogori valid.

Berdasarkan data hasil validasi tampilan oleh validator pada Tabel 5 terdapat 5 aspek yang dinilai, yaitu (1) gambar, video, dan audio; (2) tata letak; (3) kelayakan bahasa; dan (4) kemudahan penggunaan program resitasi. Hasil validasi tampilan dari keempat aspek tersebut diperoleh nilai rata-rata 3,5 dengan persentase $87,67 \%$ dengan kategori validasi yaitu valid (tidak revisi). Kriteria valid menunjukkan bahwa program resitasi yang dikembangkan layak untuk digunakan sebagai sumber belajar. Dengan demikian hasil analisis validasi isi dan tampilan menunjukkan bahwa program resitasi berbasis web dengan multirepresentasi pada materi kinematika telah valid dan dapat dilakukan uji kepraktisan.

2. Hasil uji kepraktisan
Data hasil uji kepraktisan diperoleh dengan mempersihakan mahasiswa untuk mengakses, mengamati dan mengoperasikan program resitasi yang telah dikembangkan. Kemudian mahasiswa diberikan angket penilaian yang terdiri dari beberapa aspek yang mengacu pada kemudahan dalam penggunaan program resitasi untuk mendapatkan data kuantitatif. Hasil uji kepraktisan program resitasi yang dilakukan pada mahasiswa ditunjukkan pada Tabel 6.

Berdasarkan Tabel 6 diperoleh persentase hasil uji kepraktisan sebesar 84,3\%. Hal tersebut menunjukkan bahwa program resitasi praktis untuk digunakan sebagai bahan ajar. Data hasil uji kepraktisan menunjukkan bahwa program resitasi yang dikembangkan dapat menambah semangat mahasiswa dalam belajar, mempermudah mahasiswa dalam memahami topik kinematika, dan membantu mahasiswa dalam menyimpulkan konsep kinematika.

Data kualitatif pada uji kepraktisan berupa komentar dan saran dari mahasiswa. Namun hanya beberapa komentar dan saran yang diberikan oleh mahasiswa yang dianalisis untuk merevisi produk.

Tabel 6. Hasil uji kepraktisan program resitasi

\begin{tabular}{clcc}
\hline No & \multicolumn{1}{c}{ Aspek } & Persentase (\%) & Kategori \\
\hline 1 & $\begin{array}{l}\text { Program resitasi multirepresentasi berbasis web menambah } \\
\text { semangat belajar }\end{array}$ & 85,4 & Praktis \\
2 & $\begin{array}{l}\text { Program resitasi multirepresentasi mempermudah memahamai } \\
\text { topik kinematika }\end{array}$ & 83,8 & Praktis \\
3 & $\begin{array}{l}\text { Program resitasi membantu dalam menyimpulkan konsep } \\
\text { kinematika }\end{array}$ & 83,8 & Praktis \\
4 & Program resitasi lebih menarik dan tidak membosankan & 85,8 & Praktis \\
5 & Tampilan program resitasi menarik & 79,2 & Praktis \\
6 & Bahasa yang digunakan mudah dipahami & 82,5 & Praktis \\
7 & Ukuran huruf yang digunakan jelas (terbaca) & 87,1 & Praktis \\
8 & Jenis huruf yang digunakan sesuai dan jelas (terbaca) & 87,9 & Praktis \\
9 & Gambar yang terdapat pada Program resitasi terlihat dengan jelas & 85,4 & Praktis \\
10 & Program resitasi dapat diakses dengan mudah & 82,5 & Praktis \\
\hline \multirow{2}{*}{ Rata-rata } & $\mathbf{8 4 , 3}$ & Praktis \\
\hline
\end{tabular}


Berdasarkan hasil komentar dan saran mahasiswa pada uji kepraktisan diketahui bahwa sebagian besar mahasiswa berpendapat bahwa program resitasi yang dikembangkan sudah dapat digunakan sebagai bahan ajar mandiri yang dapat menambah semangat belajar, mempermudah memahami topik kinematika, membantu dalam menyimpulkan konsep kinematika. Menurut mahasiswa desain yang disajikan dalam program resitasi terlalu ramai. Pada aspek tampilan, mahasiswa memberi saran agar warna yang digunakan sebagai background dibuat lebih cerah dan bervariasi, serta agar suara yang digunakan dalam program resitasi lebih halus.

Data kuantitatif dan kualitatif hasil uji kepraktisan menunjukkan bahwa program resitasi berbasis web dengan multirepresentasi pada materi kinematika termasuk dalam kategori praktis. Hal tersebut sejalan dengan hasil penelitian terdahulu yang menyatakan bahwa bahan ajar yang disajikan dalam bentuk web lebih efektif dan efisien dikarenakan hemat waktu dan biaya, mudah untuk diakses, serta dapat digunakan sebagai bahan ajar mandiri (Azmi et al., 2020; Amin, 2017).

Berdasarkan hasil paparan diatas, diketahui beberapa kelebihan dari program resitasi multirepresentasi berbasis web yaitu (1) dapat diakses kapan dan dimana saja, (2) dapat diakses secara online melalui jenis perangkat elektronik yang dapat terhubung internet (3) dapat diakses tanpa perlu menginstal program (4) tidak memerlukan ruang memori (5) dilengkapi feedback berupa audio visual. Sedangkan kelemahan dari program resitasi multirepresentasi berbasis web yaitu (1) diperlukan jaringan internet yang memadai untuk mengakses program (2) Tidak dapat mengawasi peserta didik dalam penggunaan program resitasi, (3) efektivitas program resitasi terhadapmahasiswa dalam proses pembelajaran belum diketahui karena program resitasi belum diterapkan di perkuliahan.

\section{Kesimpulan}

Produk akhir dari penelitian dan pengembangan ini adalah program resitasi berbasis web dengan multirepresentasi pada materi kinematika. Format dari produk yang dihasilkan adalah HTML yang dapat diakses melalui perangkat eletronik yang tehubung internet.

Berdasarkan hasil analisis validasi diperoleh persentase sebesar 93,31\% dengan kategori valid pada aspek konten produk, serta diperoleh persentase 87,67\% dengan kategori valid pada aspek tampilan produk. Adapun hasil analisis uji kepraktisan diperoleh persentase sebesar 84,33\% dengan kategori praktis. Dengan demikian dapat dinyatakan bahwa program resitasi berbasis web dengan multirepresentasi pada materi kinematika tergolong praktis dan layak untuk digunakan sebagai bahan ajar mahasiswa.

\section{Daftar Pustaka}

Abi Hamid, M., Nyeneng, I. D. P., \& Rosidin, U. (2013). Perbandingan penggunaan feedback pada lembar jawaban siswa terhadap penguasaan konsep fisika melalui pembelajaran kontekstual. Jurnal Pembelajaran Fisika, 1(5).

Aditya, D. Y. (2016). Pengaruh Penerapan Metode Pembelajaran Resitasi terhadap Hasil Belajar Matematika Siswa. SAP (Susunan Artikel Pendidikan), 1(2).

Amin, A. K. (2017). Kajian Konseptual Model Pembelajaran Blended Learning berbasis Web untuk Meningkatkan Hasil Belajar dan Motivasi Belajar. Jurnal Pendidikan Edutama, 4(2), 51-64.

Arikunto, Suharsimi. (2013). Prosedure Penelitian Suatu Pendekatan Praktik. Jakarta: PT. Rineka Cipta.

Azmi, R. A., Rukun, K., \& Maksum, H. (2020). Analisis Kebutuhan Pengembangan Media Pembelajaran Berbasis Web Mata Pelajaran Administrasi Infrastruktur Jaringan. Jurnal Ilmiah Pendidikan Dan Pembelajaran, 4(2), 303-314.

Dewi, N. R. (2013). Peningkatan Kemampuan Koneksi Matematis Mahasiswa Melalui Brain-Based Learning Berbantuan Web. Makalah Pendamping: Pendidikan Matematika, 4(1), 283-374.

Docktor, J. L., \& Mestre, J. P. (2014). Synthesis of discipline-based education research in physics. Physical Review 
Special Topics-Physics Education

Research, 10(2), 020119.

Firdaus, T., \& Sinensis, A. R. (2017). Video analisis untuk kemampuan menganalisis dan memecahkan masalah materi kinematika pada calon guru fisika. Jurnal Penelitian Pembelajaran Fisika, 8(2).

Handhika, J., Purwandari, P., Cari, C., Suparmi, S., \& Sunarno, W. (2015). Profil konsepsi mahasiswa pada materi kinematika. Seminar Nasional Pendidikan Sains V 2015.

Kirana, I. E., \& Kusairi, S. (2019). Profil Kemampuan Berpikir Kritis Mahasiswa Program Studi Pendidikan IPA dalam Kasus Grafik Kinematika Satu Dimensi. Jurnal Pendidikan: Teori, Penelitian, dan Pengembangan, 4(3), 363-368.

Maharani, N., \& Kartini, K. S. (2019). Penggunaan google classroom sebagai pengembangan kelas virtual dalam keterampilan pemecahan masalah topic kinematika pada mahasiswa jurusan sistem komputer. PENDIPA Journal of Science Education, 3(3), 167-173.

Ningrum, D. J., Mahardika, I. K., \& Gani, A. A. (2015). Pengaruh model quantum teaching dengan metode praktikum terhadap kemampuan multirepresentasi siswa pada mata pelajaran fisika kelas $\mathrm{x}$ di SMA Plus Darul Hikmah. Jurnal Pembelajaran Fisika, 4(2).

Novitasari, I. D. A., Akhdinirwanto, R. W., \& Ashari, A. (2013). Peningkatan Pola Pikir Individu Dengan Metode Pemberian Feedback Bagi Siswa Kelas X Smk Batik Perbaik Purworejo. Radiasi: Jurnal Berkala Pendidikan Fisika, 3(1), 33-36.

Pahini, N., Abdurrahman, A., \& Suana, W. (2014). Pengaruh Skill Multirepresentasi Siswa Terhadap Hasil Belajar Fisika Pada Model Pembelajaran Exclusive. Jurnal Pembelajaran Fisika, 2(5).

Pebriana, I. N., Sutopo, S., \& Diantoro, M. (2018). Dampak program resitasi terhadap pemahaman konsep mahasiswa pada topik fluida dinamis. Jurnal Pendidikan: Teori, Penelitian, dan Pengembangan, 3(8), 1110-1114.

Permadi, D., Suyatna, A., \& Suyanto, E. (2013). Pengembangan Modul Berbasis Multi Representasi Pada Materi Termodinamika. Jurnal Pembelajaran Fisika, 1(5).
Prastowo, S. H. B., Jatmiko, B., \& Supardi, Z. I. (2019). Model Apposite Untuk Meningkatkan Penguasaan Konsep Fisika Kinematika Pada Mahasiswa. JPPS (Jurnal Penelitian Pendidikan Sains), 9(1).

Pratiwi, J., Wiyono, K., \& Muslim, M. (2018). Analisis Pemahaman Konsep Fisika Materi Kinematika dengan Teknik CRI Di SMAN 1 Talang Kelapa. Sriwijaya University.

Purwanti, A., Sutopo, S., \& Wisodo, H. (2017). Penguasaan Konsep Materi Kinematika pada Siswa SMA Kelas X dengan Menggunakan Pembelajaran Multirepresentasi. Jurnal Pendidikan: Teori, Penelitian, dan Pengembangan, 2(4), 575-578.

Subali, B., Rusdiana, D., Firman, H., \& Kaniawati, I. (2015). Analisis Kemampuan Interpretasi Grafik Kinematika pada Mahasiswa Calon Guru Fisika. Simposium Nasional Inovasi dan Pembelajaran Sains (SNIPS), 269-272.

Sugiyono. (2015). Metode Penelitian Pendidikan. Bandung: Alfabeta.

Sukadi, E., \& Angraeni, L. (2019). Penerapan Pedagogical Content Knowledge Pada Materi Kinematika Untuk Meningkatkan Hasil Belajar Mahasiswa. Prosiding Seminar Nasional Pendidikan Mipa Dan Teknologi II, 1(1), 202-214.

Sutopo, Ida Bagus Rini Jayanti, \& Wartono. (2017). Efektivitas program resitasi berbasis komputer untuk Meningkatkan penguasaan konsep mahasiswa Tentang gaya dan gerak. Jurnal Inovasi dan Pembelajaran Fisika. Hal 27-35. ISSN: $2355-7109$.

Taqwa, M. R. A. (2017). Program Resitasi Berbasis Multi Representasi dan Multi Konteks untuk Meningkatkan Pemahaman Konsep Mekanika Newtonan. Tesis Tidak Diterbitkan. Pascasarjana. Universitas Negeri Malang: Malang.

Thiagarajan, S., et al. (1974). Instructional Development for Training Teachers of Exceptional Children: A Sourcebook. Indiana Univ. Bloomington. Indiana University Bloomington Indiana.

Waldrip, B., Prain, V., \& Carolan, J. (2006). Learning junior secondary science through multi-modal representations. 
Electronic Journal of Science Education, 11(1).

Yusro, A. C., \& Sasono, M. (2016). Penggunaan modul ilustratif berbasis inkuiri terbimbing pokok bahasan kinematika gerak lurus untuk meningkatkan hasil belajar dan kemandirian siswa kelas VII SMPN 14 Madiun. Jurnal Pendidikan Fisika dan Keilmuan (JPFK), 2(1), 29-35.

Waldrip, B., Prain, V. \& Carolan, J. (2006). Learning Junior Secondary Science through Multi-Modal Representations. Electronical Journal of Science Education South Western University-Preview Publication, 11(1).

Widianingtiyas, L., Siswoyo, \& Bakri, F. (2015). Pengaruh Pendekatan Multi Representasi dalam Pembelajaran Fisika Terhadap Kemampuan Kognitif Siswa SMA. Jurnal Penelitian dan Pengembangan Pendidikan Fisika, 1(1), 31-38. 